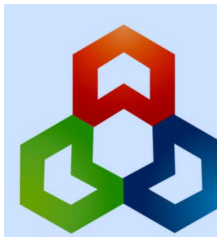

FRONTIER

RESEARCH JOURNALS

(RESEARCH ARTICLE)

\title{
Ethnobotany and phytochemical analysis of Jatropha Tanjorensis in Mubi Adamawa State, Nigeria
}

\author{
Comfort Sankem Yusuf 1, ${ }^{*}$, Ibrahim Birma Bwatanglang ${ }^{2}$, Tari Dlama Tizhe ${ }^{1}$, Peter Emmanuel Tosin ${ }^{1}$ and \\ Musa Ira Felister 3
}

${ }^{1}$ Department of Botany, Adamawa State University, Mubi, Nigeria.

${ }^{2}$ Department of Chemistry, Adamawa state University, Mubi, Nigeria.

${ }^{3}$ Department of Biology, College of Education, Zing, Nigeria.

International Journal of Frontiers in Life Science Research, 2021, 01(01), 040-047

Publication history: Received on 05 April 2021; revised on 08 May 2021; accepted on 11 May 2021

Article DOI: https://doi.org/10.53294/ijflsr.2021.1.1.0035

\begin{abstract}
This study was focused on the ethanobotanical survey, phytochemical and proximate analysis of Jatropha tanjorensis in Mubi. The ethnobotanical survey was carried out in some selected parts of both Mubi North and South local government areas through oral interview using traditional medicine practioners and some householders as the interviewee. After air drying, pulverizing and extracting the bioactive constituents of the leaf using ethanol and water as solvents, the phytochemical and proximate analysis were carried out using a standard procedures. The ethnobotanical survey showed that, J. tanjorensis were used in the study areas as a remedy to diseases such as: measles, scabies, malaria, high blood pressure, stomach ache, diabetes mellitus, eczema and anaemia with $74 \%$ of the interviewee mentioning leaves as part mostly used. The qualitative phytochemical screening indicated the presence of compounds, namely: tannins, alkaloids, phenols, flavonoids, saponins, terpenoids, glycosides and anthraquinones in both the ethanolic and aqueous leaf extracts except terpenoids which was not detected in the ethanolic extract. The quantitative analysis showed glycosides (4.12 mg/100 g) and flavonoids (3.45 mg/100 g) as the highest compound in the ethanolic and aqueous extracts respectively. Carbohydrate was shown to be the highest proximate constituent with $52.38 \%$ and fat the least with $1.76 \%$. Therefore, J. tanjorensis is rich in bioactive constituents and the leaves are mostly the plant part used as a remedy to illnesses such measles, scabies, malaria, high blood pressure, stomach ache, diabetes mellitus, eczema and anaemia.
\end{abstract}

Keywords: Ethanolic; Alkaloids; Leaves; Analysis; Jatropha

\section{Introduction}

The vast reservoir of essential elements, nutrients and phytochemicals in plants makes its number one excipient for most pharmaceutical drugs [1]. And relative to its spread and varying physiochemistry stands out exceptionally as the most accessible source of Medicare for a common man, especially in developing countries like Nigeria [2].It will suffice to further say that, essential elements, nutrients phytochemicals defined the specific therapeutic efficacy of individual plant species in the treatment and management of various diseases [3],[2]. Based on this understanding, the search and identification of active bio-molecules in plants, nowadays took a slightly different itinerary where the science of ethnobotany are used as a guide to lead researches towards different sources and classes of compounds with great medicinal importance [4],[2].

\footnotetext{
${ }^{*}$ Corresponding author: Comfort S. Yusuf

Department of Botany, Adamawa State University, Mubi, Nigeria.

Copyright (C) 2021 Author(s) retain the copyright of this article. This article is published under the terms of the Creative Commons Attribution Liscense 4.0.
} 
Ethnobotany in addition to scientific scrutiny were observed to be indispensable tools that simplified decision in the choice and application of medicinal plants for specific therapeutic purposes. For these reasons, ethnobotanical survey was conducted in this study to rationalize the importance and health-related applications of $J$. tanjorensis in Mubi, Nigeria for the treatment and management of various diseases. Mubi town is one of the biggest cattle markets in West Africa, and the second largest city in Adamawa State, Nigeria [5]. Though, the city is striving in businesses and commercial activities, the available health-care facilities in the town are invariably overstretched due to the overwhelming increase in human population, thus pushing greater number of the residence to rely on available medicinal plants such as J. tanjorensis for the treatment of various diseases. J. tanjorensis belongs to the family Euphorbiaceae, commonly known in different languages in Nigeria as "Iyana-Ipaja, lapa-lapa" or "ewe Americana" (Yoruba), "hospital too far" and "Ugu Oyingbo" (Igbo) or "Catholic vegetable" by the local folks of Benin [6], [7]. A common weed crops, gregarious shrub of about 6 meters in height, with spreading branches and stubby twinges and smooth gray bark, which gives off whitish colour latex when cut and are usually grown in the higher rainfall forest zones in West Africa [8]. The leaves are deciduous alternate but with apical crowded, orate, 3-5 lobe in outline, 6-40 cm broad, the petioles 3-8cm long. The flowers are greenish cymes, bell-shaped, sepals broadly deltoid.

Different parts of the plant have been found useful in the treatment of fever, eczema, itches, visceral diseases, stomach ache, and sores on the tongues of babies [9]. In some parts of Nigeria the leaves of J. tanjorensis are locally consumed as vegetables added to daily meals, and also in the treatment of diabetes mellitus [10]. It is also used to improve the hematological indices and bone marrow function in animal models [11]. The Leaf extract has been reported to possess ingredients capable of lowering blood cholesterol level and might be useful in the treatment of cardiovascular diseases caused by hyper-lipidemia [12].

As mentioned earlier, ethnobotanical study helps researchers rationalized plants species with specific therapeutic efficacy, converting the information derived from the study to health-based data. The information is derived from personal communications with herbal retailers, traditional health practitioners and local communities that uses plantbased Medicare [13]. This approached were adopted by many researchers in profiling Nigerian plants-species with varying medicinal importance [14]-[17] in the treatment of diarrhea [18], [19], skin disease such as Measles [20] and in the treatment of viral infections [21]. Despite the fact that the science of ethnobotany contributed immensely in rationalizing plants species with great medicinal importance, it's however often difficult to present a universal picture on the properties and functional uses of such findings due to the ubiquitous nature of plants species and their peculiarities; bearing in mind extreme variations such as culture, geography, and socio-economic considerations. In an attempt to navigate through these variations, this present study was conducted toward establishing the medicinal importance of $J$. tanjorensis in Mubi, Adamawa state through ethnobotanical survey. The study further integrated the survey findings with the proximate and phytochemical components of the plants with the view to establishing a scientific reason for its potency in the treatment of various diseases by the people in the study area.

\section{Material and methods}

\subsection{Sampling and Data Collection}

The plant samples, the vegetative and floral parts were collected in some selected parts of Mubi North and Mubi South Local Government Areas of Adamawa State, North Eastern, Nigeria. The plant sample was authenticated by a taxonomist at the Department of Botany, Adamawa State University, Mubi, Nigeria. The ethnobotanical data were collected using method described by [22] Oral interview was conducted using Traditional Medicine Practitioners [TMPs] and knowledgeable respondents as participants in collecting information on the plant for curative purpose in the study area. A total of 52 households were interviewed in Mubi south and north respectively. As shown in Figure 1, the sampling areas were located in the North Eastern region of Nigeria between latitude $10^{0} 14 \mathrm{~N}^{1}$ and $10^{0} 18^{1} \mathrm{~N}$ of the equator and longitude $13^{0} 14^{1} \mathrm{E}$ and $13^{0} 19^{1} \mathrm{E}$. It occupies a land of about $725.85 \mathrm{Km}^{2}$. The area has a tropical climate with an average temperature of $32^{\circ} \mathrm{C}$ and lies within the Sudan Savanna vegetation zone of Nigeria. The area has an average relative humidity ranging from $28 \%-45 \%$ and an annual rainfall of about $1056 \mathrm{~mm}$ [23].

\subsection{Sample Extraction and Preparation}

The ethanolic and aqueous leaf extracts of the samples were prepared by taking $100 \mathrm{~g}$ of the dried powdered leaf in 500 $\mathrm{ml}$ of the respective solvents, and aged at room temperature for 48 hours, followed by filtration and further concentrated in a water bath at $40^{\circ} \mathrm{C}$. The obtained concentrated filtrate was then transferred into a sample bottle and stored in a refrigerator prior to analysis. High performance liquid chromatography (HPLC) techniques were used for the phytochemical analysis of the plant leaf extract. For the analysis, a known amount of the sample in hexane was injected into HPLC (Buck Scientific (USA) BLC10/11) with a fluorescence detector (excitation at $295 \mathrm{~nm}$ and emission 
at $325 \mathrm{~nm})$ and an analytical silica column $(25 \mathrm{~cm} \times 4.6 \mathrm{~mm})$. The mobile phase used was hexane: tetrahydrofuran: isopropanol (1000:60:4 v/v/v) at a flow rate of $1.0 \mathrm{ml} / \mathrm{min}$. Standard samples were also prepared using a similar method.

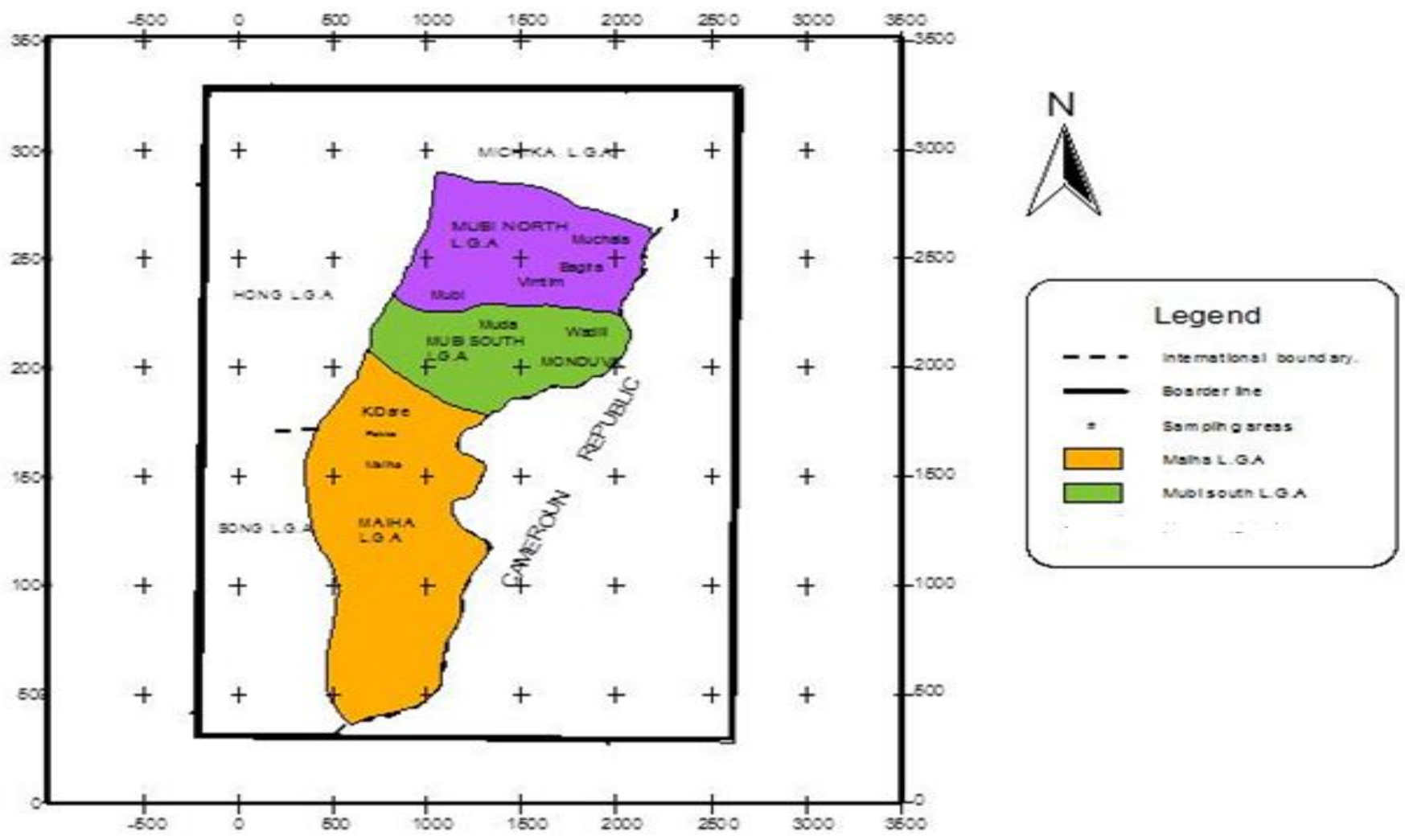

Figure 1 Sampling Location

\section{Results}

The results of the ethno-botanical survey of Jatropha tanjorensis in both Mubi-South and Mubi-North is represented in Table 1.

Table 1 Ethno-botanical Survey of the J. tanjorensis

\begin{tabular}{|c|c|c|c|c|}
\hline $\begin{array}{ll}\text { Plant } & \text { Parts } \\
\text { Used } & \end{array}$ & $\begin{array}{l}\text { Disease } \\
\text { Condition }\end{array}$ & Mode of preparation & $\begin{array}{l}\text { Household } \\
\text { in Mubi- } \\
\text { South (\%) }\end{array}$ & $\begin{array}{l}\text { Household } \\
\text { in Mubi- } \\
\text { North (\%) }\end{array}$ \\
\hline Tender-leaf & Measles & Maceration leave Mixed with milk & 16.67 & 17.86 \\
\hline Leaves & Scabies & Maceration Leaves plus scent leaves & 8.33 & 7.14 \\
\hline Leaves & Malaria & Soup and drinking The macerated liquid & 16.67 & 17.86 \\
\hline Leaves & $\begin{array}{l}\text { High blood } \\
\text { pressure }\end{array}$ & Maceration leave Mixed with milk & 8.33 & - \\
\hline $\begin{array}{l}\text { Tender- } \\
\text { leaves }\end{array}$ & Stomach-ache & Maceration leave Mixed with milk & 8.33 & 3.57 \\
\hline Leaves & Hypertension & Macerated leave or taken as soup & 4.17 & 7.14 \\
\hline Leaves & $\begin{array}{l}\text { Diabetes } \\
\text { Mellitus }\end{array}$ & Maceration leave Mixed with milk & - & 7.14 \\
\hline Latex & Eczema & Macerated leave applied on infested Parts & - & 7.14 \\
\hline \multirow[t]{3}{*}{ Leaves } & \multirow[t]{3}{*}{ Anaemia } & Cooking the leaves as soup & 29.17 & 25 \\
\hline & & Mixing the leaves with 0. gratissimum & - & 7.14 \\
\hline & & Macerated leave & 8.33 & - \\
\hline
\end{tabular}


The results show that about $29.17 \%$ of the household used the leaves as cooked soup for the treatment of anemia, while about $16.17 \%$ used it in macerated form mixed with milk for the treatment of measles and the macerated liquid extract for the treatment of malaria. Only about $4.17 \%$ indicated using the leaves in the control of hypertension in macerated form mixed with milk. Similar trends were observed in Mubi-North, showing 25\% of the household used the leaves in the treatment of anemia, and $\mathbf{1 7 . 8 6} \%$ for malaria and measles. While no information on the use of the leaves in the treatment of diabetes mellitus by the Mubi-south household, about $7.14 \%$ of the household in Mubi-North indicated using the same in the treatment of diabetes mellitus.

The plant part used in the treatment of various disease conditions are represented in Figure 2 . In the figure, about $74.55 \%$ of the household interviewed indicated using the leaves in the treatment of various illnesses, while only $21.82 \%$ indicated using the Tender-leaves. Only about 3.63\% used the Latex specifically to treat Eczema.

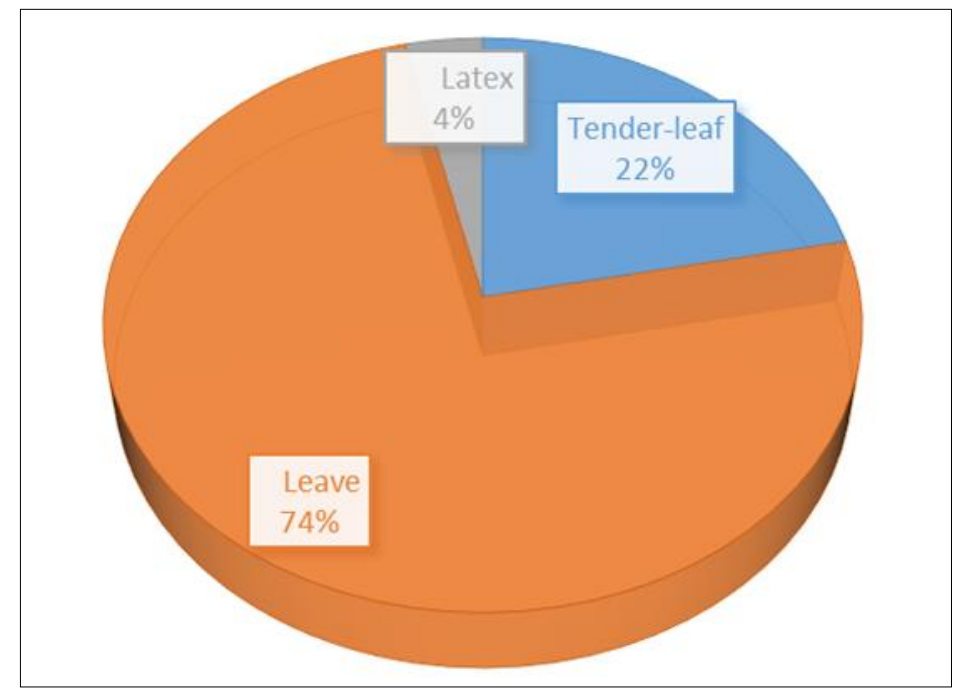

Figure 2 Percentage of Parts Used in the Treatment of Diseases

The phytochemical analysis of the leaves extracts as presented in Table 2 shows the presence of tannins, alkaloids, phenol, flavonoids, Saponins, glycosides and anthraquinones in both the ethanolic and aqueous extract. Terpenoids were not detected in the ethanolic extract but however present in the aqueous extract.

Table 2 Qualitative Phytochemical Analysis of J. tanjorensis Leaf Extract

\begin{tabular}{|l|l|l|l|}
\hline S/N & Chemical & Ethanol & Aqueous \\
\hline 1 & Tannins & + & + \\
\hline 2 & Alkaloids & + & + \\
\hline 3 & Phenol & + & + \\
\hline 4 & Flavonoids & + & + \\
\hline 5 & Saponins & + & + \\
\hline 6 & Terpenoids & - & + \\
\hline 7 & Glycosides & + & + \\
\hline 8 & \multicolumn{4}{|l|}{ Anthraquinones } & + & + \\
\hline \multicolumn{5}{|c|}{$+=$ present - = absent } \\
\hline
\end{tabular}

Quantitatively, the phytochemicals with the highest concentration (mg/100) in the ethanolic leaves extract of the $J$. tanjorensis as shown in Table 3 is glycoside $(4.12 \mathrm{mg} / 100)$ followed by alkaloids $(3.56 \mathrm{mg} / 100)$. The concentration obtained from the ethanolic extract was observed to be higher than the values from the aqueous leaves extract. The phytochemical with the highest concentration in the aqueous extract is flavonoid (3.45 mg/100) followed by alkaloids (1.02 mg/100) 
Table 3 Quantitative phytochemical Constituents of Leaf extract mg/100

\begin{tabular}{|l|l|l|l|}
\hline S/N & Chemical & Ethanol & Aqueous \\
\hline 1 & Tannins & 1.33 & 0.62 \\
\hline 2 & Alkaloids & 3.56 & 1.02 \\
\hline 3 & Steroids & 0.13 & 0.07 \\
\hline 4 & Phytates & 0.15 & 0.11 \\
\hline 5 & Flavonoids & 2.15 & 3.45 \\
\hline 6 & Saponins & 0.33 & 0.18 \\
\hline 7 & Terpenoids & 0.16 & 0.05 \\
\hline 8 & Glycosides & 4.12 & 0.22 \\
\hline 9 & Anthraquinones & 0.77 & 0.29 \\
\hline
\end{tabular}

The proximate composition of the Jatropha tanjorensis leaf shows carbohydrate as the most abundant constituent, constituting about $52.38 \%$ of the composition followed by protein $(18.15 \%)$ and a moisture content of about $10.75 \%$. The results are shown in Figure 3.

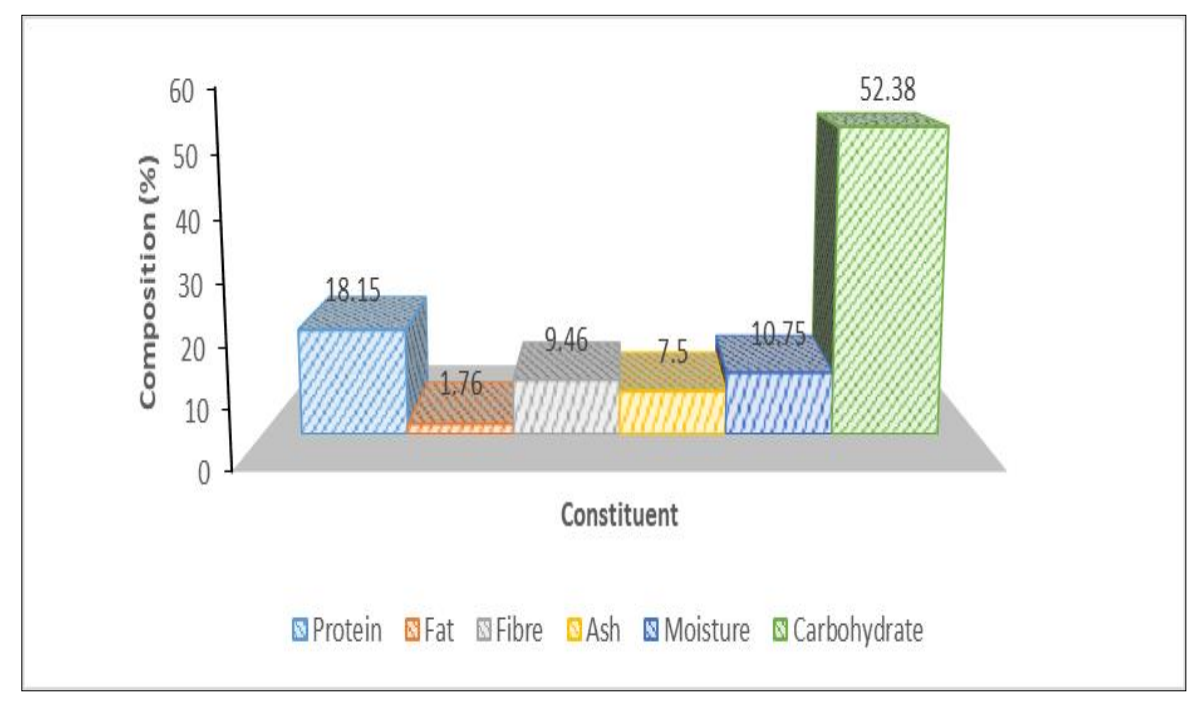

Figure 3 Proximate Composition of Jatropha tanjorensis leaf

\section{Discussion}

The consumption of leafy vegetables is part of Africans' cultural heritage and they play important roles in the tradition and food culture of many African households [24]. Nigeria is endowed with a variety of indigenous green leafy vegetables which are consumed by various groups for different reasons. The indigenous use of plants and plant materials has been from time immemorial. People from the rural areas relied absolutely on plants growing in the wild for the treatments of various diseases [25]. Also previous studies by [26] and [27] revealed that a wide variety of plants are known to be used as herbal remedies for the treatment of different diseases. The active ingredients for a vast number of pharmaceutically derived medications contain components originating from phytochemicals [28]. Despite the effectiveness of chemically synthesized drugs, screening plants for drugs has continued for the development of new pharmaceuticals to resolve both old and new health problems. Research studies, such as those of [29] and [30], had revealed that the extracts from medicinal plants species have different chemical composition that are essential for the physiological functions of human body, hence the plants have potential for use in treatment of different ailments and play important role in satisfying human needs for energy and life processes. 
The ethno-botanical survey of $J$. tanjorensisin the study area revealed that the plant is used in treating malaria, fever, diabetes mellitus, eczema, measles, high blood pressure, stomach ache, anaemia, scabies on the skin (Table 1). The result agrees with [7], [10], [31], [6] and [9] who reported that the plant is used in treatment of diseases. The survey also revealed that the leaf of the plant were the most used, constituting $74.55 \%$, followed by the tender-leaf $(21.82 \%)$ and the latex (3.64\%) respectively (Figure 2), which corresponds with the report of [29], [36] and [8] that the leaves of the plant are used for curative purposes.

The phytochemical screening of the leaf extract showed the presence of phytochemicals such as: Flavonoids, Alkaloids, Tannins, Terpenoids, Saponins, Anthraquinones, Steroids, Glycosides and Phenols; but Terpenoids is negative in leaf ethanolic extract of the plant. The phytochemical result of this present study is in line with the findings of [32] and [12] who reported the presence of these phytochemicals in the leaves of the plant. The presence of these compounds is an indication that the plant might offer medicinal benefits to its users as phytochemicals have been shown to confer protection on human health [33], [34]. Apart from their roles in human health, phytochemicals also play important roles in plant survival. They give plants their colour, flavour, aroma and are parts of a plant's natural defense system protecting them from environmental hazards such as stress, UV exposure and pathogenic attacks [35]. The presence of these phytochemicals as shown in this study could be responsible for the lush green colour of the plant and its ability to resist insect pests. [36] showed that phenolics (especially flavonoids) are able to alter peroxidation kinetics by modifying the lipid packing order. They stabilize membranes by decreasing membrane fluidity (in a concentrationdependent manner) and hinder the damage by free radicals and restrict peroxidative reactions [36], [37]. The presence of alkaloids in the extract might be responsible for the plant's use in the treatment of malarial infection and hypertension as reported by [6]. The use of the leaves of J. tanjorensis to treat venereal diseases as reported by [31] could be due to the presence of tannins as obtained in the leaf extract in this study. Tannins have been reported to possess antimicrobial activities as they inhibit the growth of many viruses, bacteria, fungi and yeast.

\section{Conclusion}

Different parts of $J$. tanjorensis especially the leaves are used by the inhabitants of Mubi local government area as a remedy to diseases such as measles, scabies, malaria, high blood pressure, stomach ache, diabetes mellitus, eczema and anaemia. Leaves of $J$. tanjorensis are rich in bioactive compounds which include: tannins, alkaloids, phenols, flavonoids, saponins, terpenoids, glycosides and anthraquinones. The leaves contain varied quantities of proximate constituents with carbohydrate being the highest with $52.38 \%$ and fat with $1.76 \%$ the least.

\section{Compliance with ethical standards}

\section{Acknowledgments}

The authors wished to thank all the laboratory technology for assisting in the phytochemical analysis of this study.

\section{Disclosure of conflict of interest}

The authors declared no conflict of interest.

\section{References}

[1] Newman GM and Cragg DJ. Natural Product as asources of New Drugs over 30 years from 1981 to $2010 . \mathrm{J}$ Nat Prod. 2012; 75:311-335.

[2] Magili TS and Bwatanglang IB Determination of Macro and Micro Elements in Some Selected Anti-diabetic Medicinal Plants in Adamawa State, Nigeria Using Instrumental Neutron Analysis. WWJMRD. 2018; 4(6):181190.

[3] Sabandar CW, Ahmat N, Jaafar FM and Sahidin I. Medicinal property, phytochemistry and pharmacology of several Jatropha species (Euphorbiaceae): a review. Phytochemistry. 2013; 85:7-29.

[4] Devis S, Kumar D and Kumar M. Ethnobotanical values of antidiabetic plants of MP region. India. Journal of Medicinal Plants Studies. 2016; 4(3):26-28.

[5] Bwatanglang IB, Alexander P and Timothy NA. Vehicle-Derived Heavy Metals and Human Health Risk Assessment of Exposure to Communities along Mubi-Yola Highway in Adamawa State (Nigeria). JSRR. 2019; 23(1):1-13. 
[6] Iwalewa EO, Adewunmi CO, Omisore NO, Adebanji OA and Azike CK. Prooxidant effects and cytoprotective potentials of nine edible vegetables in Southwest Nigeria. Journal of Medicinal Foods. 2005; 8:539-544.

[7] Sofowora, A. Medicinal Plants and traditional Medicine in Africa. Spectrum Books Ltd., Ibadan, Nigeria, 1993.

[8] O'Hara MD, Kiefer K and Kemper T A review of 12 commonly used medicinal herbs. Arch. Family Med. 1998; 7:523-536.

[9] Taofeeq O, Ganiyu OA, Tesleem AO, Godwin OA and Mutiyat AO. Mechanism of action of jatrophagossypifolia stem latex as a haemostatic agent, Eur J. Gen Med. 2005; 2(4):140-3.

[10] Olayiwola G, Iwalewa EO, Omobuwajo OR, Adeniyi AA and Verspohi E J The antidiabetic potential of Jatropha tanjorensis leaves. Nig. J. Nat. Prod. Med. 2004; 8:55-58.

[11] Orhue ES, Idu M, Ataman JE and Ebite LE. Haematological and histopathological studies of Jatropha tanjorensis leaves in rabbits. Asian Journal of Biological Sciences. 2008; 1(2):84-89.

[12] Oyewole OI and Akingbala PF. Phytochemical analysis and hypolipidemic properties of Jatropha tanjorensisleaf extract. European Journal of Medicinal Plants. 2011; 1(4):180-185.

[13] Adebayo-Tayo BC, Adegoke AA, Okoh AI and Ajibesin KK. Rationalizing some medicinal plants used in the treatments of skin diseases. African Journal of Microbiology Research. 2010; 10:958-963.

[14] Awoyemi OK, Ewa EE, Abdulkarim IA and Aduloju AR. Ethno-botanical Assessment of herbal plants in Southwestern Nigeria. Academic Research International. 2012; 2:50-57.

[15] Danjuma MN and Darda'u H. An Ethno-survey of Medicinal Trees of Kabobi Village, Northern Katsina, Nigeria Academic Research International. 2013; 4(3):3.

[16] Ige OE. Preliminary Investigations on the ethnomedicinal plants of Akoko Division, South West Nigeria. Global Journal of Health Sciences. 2011; 3:2.

[17] Ariyo A. Determinants of Medicinal Plants Usage for Traditional Herbal Medicine among Villagers in Ibadan, Oyo State, Nigeria AJRAF. 2018; 1(2):1-14.

[18] Agunu A, Yusuf S, Andrew GO, Zezi AU, Abdulrahman EM. Evaluation of five medicinal plants used in diarrhoea treatment in Nigeria. Journal of Ethnopharmacology. 2005; 27-30.

[19] Offiah NV, Makama S, Elisha IL, Makoshi MS, Gotep JG and Dawurung CJ. Ethnobotanical survey of medicinal plants used in the treatment of animal diarrhoea in Plateau State, Nigeria. BMC Veterinary Research. $2011 ; 36$.

[20] Sonibare MO, Moody JO and Adesanya EO. Ethnobotanical survey of plants used in the treatment of Measles. Journal of Pharmacy. 2009; 2:3-9.

[21] Oladunmeye MK and Kehinde FY. Ethnobotanical survey of medicinal plants used in treating viral infections among Yoruba tribe South Western Nigeria. African Journal of Microbiology Research. 2011; 5(19):2991-3004.

[22] Saunders M, Lewis P and Thornhill A. "Research Methods for Business Students" 6th edition, Pearson Education Limited, 2012.

[23] Mensah JK, Okoli RI, Ohaju-Obodo JO and Eifediyi K. Phytochemical, nutritional and medical properties of some leafy vegetables consumed by Edo people of Nigeria. African Journal of Biotechnology. 2008; 2304-2309.

[24] Adebayo AA. Mubi Region Geographic Synthesis 1st Edition paracelete publishers, Yola, Nigeria, 2004.

[25] Edeoga HO, Okwe DE and Mbaebie BO. Phytochemical constituents of some Nigerian medicinal plants. Afr. J. Biotechol. 2005; 4(7):685-688.

[26] Kayode J, Olanipekun MK and Tedela PO. Medicobotanical studies in relation to veterinary medicine in EkitiState, Nigeria. Checklist of botanicals used in treating poultry diseases, Ethnobotanical leaflets. $2009 ; 13$.

[27] Lewis WH and Manony PFE. Medical Botany: Plant Affecting Man's Health. John Willy and Sons, New York, USA, 1977.

[28] Iwu MM. Traditional Igbo Medicine. Institute of African Studies, University of Nigeria, Nsukka, 1983.

[29] Dingman SL. Water in soils. Infiltration and redistribution. Physical hydrology, second edition, Upper saddle river, New Jersey: Prentice - Hall, 2002.

[30] Matthews CE, Van-Holde KE and Ahem KG. Biochemistry, 3 ${ }^{\text {rd }}$ edition.) Benjamin Cummings. Conceptos de Genética, 1999. 
[31] Oduola T, Adeosun GO, Oduola TA, Avwioro GO and Oyeniyi MA. Mechanism of action of Jatropha gossypifoliastems latex as a haemostatic agent. European Journal of General Medicine. 2005; 2(4):140-143.

[32] Ehimwenma SO and Osagie AU. Phytochemical screening and anti-anaemic effects of Jatropha tanjorensis leaf in protein malnourished rats. Plant Archives, 2007; 7(2):509-516.

[33] Criagg GM and David JN. Natural product drug discovery in the next millennium. J. Pharm. Biol. 2001; 39:8-17.

[34] Tella IO and Ojo 0. Hepatoprotective effects of Azadirachtaindica, Tamarindusindicaand Eucalyptus camaldulensison paracetamol-induced hepatotoxicity in rats. Journal of Sustainable Development in Agriculture and Environment. 2005; 1(1):77-85.

[35] Agte VV, Tarwadi KV, Mengale S and Chiplonkar SA. Potentials of indigenous green vegetables as natural sources of fortification of eight micronutrients. Journal of Food Composition Analysis. 2000; 13:885-891.

[36] Arora A, Byrem TM, Nari MG and Strasburg GM. Modulation of liposomal membranes fluidity by flavonoids and is of flavonoids. Archives of Biochemistry and Biophysics. 2000; 373:102-112.

[37] Blokhina 0, Virolain EE and Fagerst EKV. Antioxidants, oxidative damage and oxygen deprivation stress: A review. Annals of Botany. 2003; 91:179-185. 